\title{
Histological study on acute inflammatory reaction to polyurethane-coated silicone implants in rats ${ }^{1}$
}

\author{
Estudo histológico da reação inflamatória aguda ao implante de silicone revestido com \\ poliuretano em ratos
}

\author{
Paulo Roberto da Silva Mendes ${ }^{\mathrm{I}}$, Jorge Bins-Ely" ${ }^{\mathrm{II}}$ Eduardo Arnaut dos Santos Lima ${ }^{\mathrm{III}}$, Zulmar Antonio Accioli de \\ Vasconcellos $^{\mathrm{IV}}$, Armando José d'Acamporav ${ }^{\mathrm{V}}$, Rodrigo d' Eça Neves ${ }^{\mathrm{VI}}$ \\ I Plastic Surgeon, University Hospital, Santa Catarina, Brazil. \\ II PhD, Associate Professor, Department of Surgery, UFSC, Brazil. \\ III Plastic Surgeon, University Hospital, Santa Catarina, Brazil. \\ iv PhD, Associate Professor, Department of Surgery, UFSC, Brazil. \\ v PhD, Associate Professor, Department of Surgery, UFSC, Surgeon-in-Chief of Florianopolis Hospital, Santa Catarina, Brazil.. \\ ${ }^{\text {VI }}$ Full Professor, Department of Surgery, UFSC, Surgeon - in-Chief of Plastic Surgery Unit, University Hospital, Santa Catarina, Brazil.
}

\begin{abstract}
Purpose: Evaluating histologically the silicone peri-implant coated by polyurethane inflammation associated to the use of anti-microbial and bacterial contamination. Methods: It was used 35 Wistar rats. The animals were divided in seven groups: I - Control; II — implant cavity contamination with 10 bacteria $/ \mathrm{ml}$; III - implant cavity contamination with 10 bacteria/ml; IV — implant cavity contamination with 10 bacteria/ml; V — identical contamination to group II and implant immersions in anti-microbial solution; VI — identical contamination in group III and implant immersions in the anti-microbial solution; VII —identical contamination of group IV and implant immersions in anti-microbial solution. It was evaluated morphometrically the peri-implant capsules after 30 days of introduction. Results: The factors with more discriminating power were the giants cells of a strange body and the mononuclear. There was no correlation between the bacterial concentrations and the histological alterations. Conclusion: 1) The histological standard of the inflammatory reaction around the silicone implant coated with polyurethan is chronic granulomatosis type of a strange body; 2) There isn't correlation between concentration of Staphylococcus epidermidis and histological changes; 3) The use of anti-microbial solution decreased the mononuclear cell reactions, with the increase of giant cells in a strange body.
\end{abstract}

Key words: Implants. Silicone. Polyurethane. Staphylococcus cutaneous infections. Wistar Rats

\section{RESUMO}

Objetivo: Avaliar, histologicamente, a reação inflamatória aos implantes de silicone revestidos por poliuretano, com contaminação bacteriana, associada ou não ao uso de antimicrobianos. Métodos: Utilizou-se 35 ratos Wistar. Os animais foram divididos em 7 grupos: I- Controle, II- contaminação da cavidade do implante com $10^{1}$ bactérias $/ \mathrm{ml}$, III- contaminação da cavidade do implante com $10^{3}$ bactérias $/ \mathrm{ml}$, IV- contaminação da cavidade do implante com $10^{5}$ bactérias $/ \mathrm{ml}$, Vcontaminação idêntica ao grupo II e imersão dos implantes em solução antimicrobiana, VI- contaminação idêntica do grupo III e imersão dos implantes em solução antimicrobiana, VII- contaminação idêntica do grupo IV e imersão dos implantes em solução antimicrobiana. Avaliou-se morfometricamente as cápsulas peri-implantes após 30 dias da introdução. Resultados: Os fatores com maior poder discriminante foram as células gigantes de corpo estranho e os mononucleares. Não houve correlação entre as concentrações bacterianas e as alterações histológicas.Conclusões: 1) O padrão histológico da reação inflamatória ao redor dos implantes de silicone revestidos com poliuretano é do tipo crônica granulomatosa de corpo estranho; 2) Não há correlação entre a concentração de bactérias Staphylococcus epidermidis e as alterações morfométricas; 3) O uso de solução antimicrobiana diminui a reação de células mononucleares, com aumento de células gigantes de corpo estranho.

Descritores: Implante. Silicone. Poliuretanos. Infecções cutâneas estafilocócicas. Ratos de Wistar. 


\section{Introduction}

The change in beauty patterns has increasingly led women to seek a plastic surgeon in order to correct alterations in breast volume and consistency through the use of breast implants. Breast augmentation attempts have been taking place for a long time, so has the use of autogen tissue, which was originally utilized for that purpose.

Several experiments have been conducted in this field: dermofatty and dermo-fascia-fatty grafts, dermo-fatty pedicle flaps in the mammary groove, fat originated from lipoaspiration, alloplastic substances, among many others. In 1961 a silicone injection was first used by Uchida. ${ }^{1}$ Later et al. $^{2}$ and Ortiz-Monasterio and Trigos ${ }^{3}$ used allopastic substances. In both cases complications were described following the breast augmentation procedure. There have also been attempts with regards to the cosmetic augmentation of breasts through the use of polyvinylether, polyurethane and polytetrafluorethylene-based sponges, which also presented complications, revealing firm capsular contracture, stiffness, irregularities, asymmetry and immobility. Infection and chronic drainage have also occurred. Such results were not aesthetically satisfactory and the complication symptoms were not tolerated by the patients. In 1973 there were other frustrated attempts with regards to stiffness and evidement using inflatable prostheses.

During the Second World War, Dow-Corning ${ }^{\circledR}$ developed silicone gel to serve as an insulating agent. The first clinical trial with silicone gel was carried out in 1962. From then on several adaptations and improvements have been necessary, such as including silicone inside a thin and solid silicone membrane, changing the internal surface of the implant, among others.

In 1986, Caffee $^{4}$ demonstrated an important decrease in thickness and capsular contracture with the use of implants with a low leak rate as compared to regular implants. Clinical data revealed that retro-mammary saline implants produced capsular contracture in $27 \%$ of the cases and the ones with silicone gel in $56 \%$ of the cases.

The following series, Melmed ${ }^{5}$, Hester et al. ${ }^{6}$ and Shapiro ${ }^{7}$ totalled a description of 1000 patients, observing capsular contracture in 1 to $2 \%$ of the cases in a 2-to-6-year followup, regardless of retro-glandular or retro-mammary approach.

Occasional reactions were observed, such as erythema, edema and a burning sensation in some patients. Such findings were self-limited and responded to symptomatic treatment. The polyurethane implant became the implant of choice in the treatment of breasts with capsular contracture. Other studies demonstrated that the polyurethane cover, after weeks to months, detached from the silicone gel cover and the polyurethane fragments thus became incorporated in the peri-implant capsule.

In the 80 's, the silicone implant with a texturized surface was conceived, which in theory would have the same advantages as those of polyurethane-coated surface without the adverse effects. Such facts and in vitro findings voluntarily contributed for U.S. manufacturers to remove polyurethane-covered implants from the market in 1991.
The fibrous capsule contracture which forms around breast implants is uncertain and probably multi-factorial, being the object of several human and animal trials in which the most common and undeniable finding is the existence of a relationship between the fibrous capsule and subclinical infection with various types of bacteria, the main one reported being Staphylococcus epidermidis ( $S$. epidermidis), present in $67 \%$ of mammilary secretions and in $17 \%$ of infected implant cultures.

In 2000, Adams $^{8}$ conducted an in vitro study evaluating the use of anti-microbial substances against the main bacteria types related to the etiology of capsular contracture. The experimental trials investigated to study the etiology of capsular contracture were carried out using silicone breast implants without polyurethane coating. The periimplant histological analysis of connective tissue inflammatory reaction is not described in depth in the majority of these trials.

The motivation for this trial was the need to evaluate inflammatory reaction around polyurethane-coated silicone implants, also studying possible histological alterations related to the use of anti-microbial agents and bacterial contamination.

The purpose was to evaluate, histologically, the inflammatory reaction to polyurethane-coated silicone implants, with bacterial contamination associated or not with the use of antimicrobial agents.

\section{Methods}

Thirty-five adult female albino rats of Wistar strain (Rattus norvergicus albinus, Rodentia mamalia) were used, their mean age being 4 months and average weight 180 grams. The rats were given only water in the 12 hours prior to the experiment and were later divided into 7 groups.

\section{Animal groups}

Group I - Control Group (n=5) - The cavity formed by means of dissecting the animals' dorsum to lodge the implant was not contaminated and the implants were not immersed in the antimicrobial solution.

Group II (n=5) - Contamination of the cavity with $0.5 \mathrm{ml}$ of the $10^{1}$ bacteria $/ \mathrm{ml}$ solution prior to implant placement.

Group III (n=5) - Contamination of the cavity with $0.5 \mathrm{ml}$ of the $10^{3}$ bacteria $/ \mathrm{ml}$ solution prior to implant placement.

Group IV (n=5) - Contamination of the cavity with $0.5 \mathrm{ml}$ of the $10^{5}$ bacteria $/ \mathrm{ml}$ solution prior to implant placement.

Group V (n=5) - Contamination of cavity in $0.5 \mathrm{ml}$ of the $10^{1}$ bacteria/ml solution and immersion of implants in antimicrobial solution. 
Group VI (n=5) - Contamination of cavity in $0.5 \mathrm{ml}$ of the $10^{3} \mathrm{bacteria} / \mathrm{ml}$ solution and immersion of implants in antimicrobial solution

Group VII (n=5) - Contamination of cavity in $0.5 \mathrm{ml}$ of the $10^{5} \mathrm{bacteria} / \mathrm{ml}$ solution and immersion of implants in antimicrobial solution

\section{Bacterial culture}

The Staphylococcus epidermidis (ATCC 35547) was supplied by the Microbiology Unit of the UFSC University Hospital. The $10^{1}, 10^{3}$ and $10^{5}$ concentrations were obtained by means of dilution using the Mac Farland scale.

The Mac Farland scale consists of indirectly measuring a bacterial suspension according to its degree of turbidity, that is, the capability to disperse light. Normally, tube number 1 of the Mac Farland scale is considered to correspond to a sample of 300,000 bacteria per milliliter.

\section{Implants}

The implants used were of silicone gel coated with polyurethane foam, with a volume of $2 \mathrm{ml}, 2 \mathrm{~cm}$ in diameter by $1 \mathrm{~cm}$ in height, with a rounded shape, one surface being flat and the other being convex.

\section{Antimicrobial solution}

The antimicrobial solution used was composed of $50 \mathrm{ml}$ iodine-povidone, $1 \mathrm{~g}$ sodium cefalozine, $80 \mathrm{mg}$ gentamicine sulphate and $500 \mathrm{ml}$ sterile saline solution, in which the material to be implanted was involved for 5 minutes.

\section{Anesthetic procedure}

After weighing, the animals were given an intramuscular injection containing sodium pentobarbital $3 \%$ $35 \mathrm{mg} / \mathrm{Kg}$ of body weight.

The effectiveness of the anesthetic was assessed by the absence of movement in the corneal-palpebral reflex (cornea palpebrae) and by the inexistence of motor reaction after prehension, with a forceps, of the fatty cushion on one of the legs (membrum pelvinum). Once the anesthetic plan was proven, the animals were submitted to the operatory procedure.

\section{Operatory procedure}

After achieving the anesthetic plan, the animals were placed in the prone position on wooden boards $30 \times 35$ $\mathrm{cm}$ and fixed with wires on their paws (membrum thoracicum) and legs (membrum pelvinum). Epilation was done on an area of approximately $4 \times 5 \mathrm{~cm}$ in the dorsal region, followed by antisepsis with chlorexidine digluconate at $4 \%$. Dieresis was conducted with a scalpel blade \#15 and complemented with Metzenbaum scissors up to a $2.5 \mathrm{~cm}$ lenghth in the podocephalic direction over the spinal chord region. A detachment was conducted with scissors and desiccation forceps to form a big enough cavity which would allow for the implant to be placed between the aponeurosis and the subcutaneous tissue. (Figure1A and B).

When the implant accomodation was considered to be adequate in the cavity formed, surgical wound edge synthesis was conducted by means of continuous stitches with nylon 5-0 thread (Figure 1C and D).

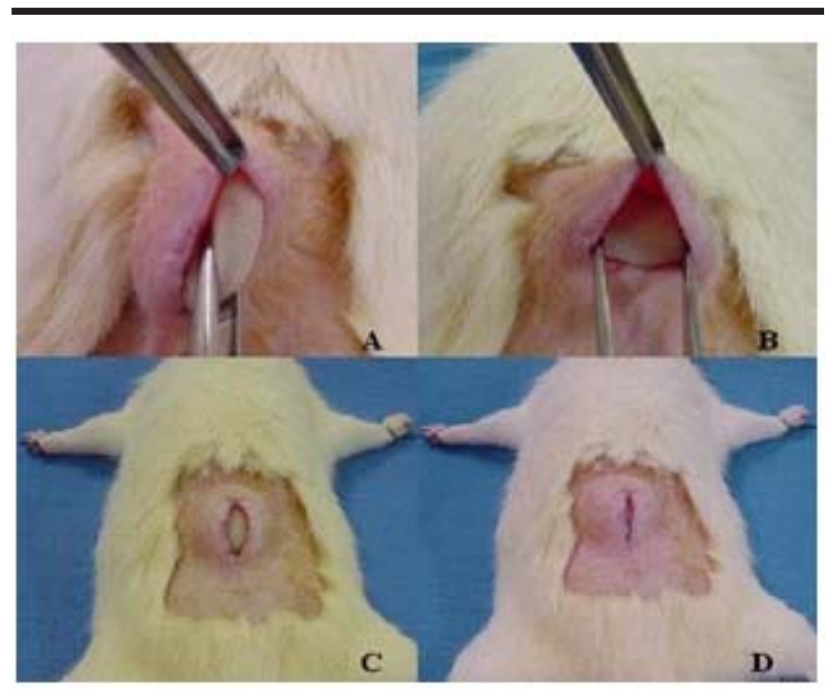

FIGURE 1 - Polyurethane-coated silicone implant being placed between the aponeurosis and the subcutaneous tissue (A, B, C and D).

Implant removal procedure

Thirty days after the experiment, all animals were submitted to euthanasia through the inhalation of ethylicether in a closed compartment. The absence of respiratory movements and corneal-palpebral reflex was verified prior to implant removal to confirm animal death.

The epidermis, dermis, posterior capsule, implant and anterior capsule were removed in a single block from all animals, by means of incision with a scalpel blade \#15 with a $1 \mathrm{~cm}$ peri-implant margin for histological studies (Figure $2 \mathrm{~A}$ and $\mathrm{B})$.

Operatory specimens were fixed in formaline in a bottle with a volume equivalent to 3 times the specimen volumes, with the bottles duly identified and individualized.

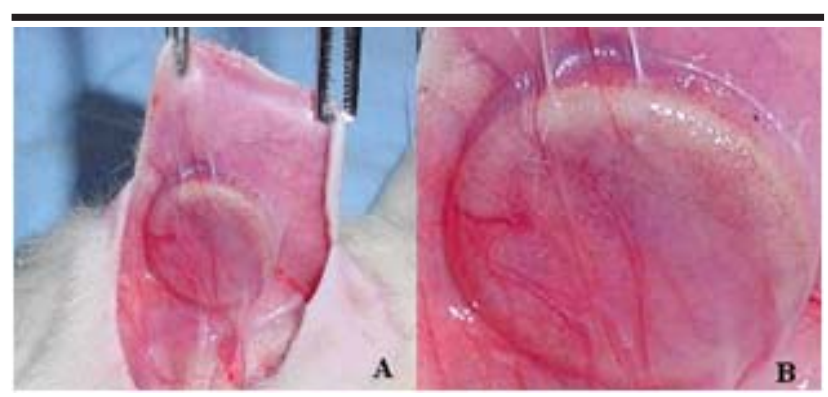

Figure 2 and B - Removal of the epidermis dermis, posterior capsule, implant and anterior capsule, implant and anterior capsule, in a sigle block. 


\section{Morphometric evaluation}

Three parallel cross sections $2 \mathrm{~mm}$ apart were obtained from each operatory specimens. The first section was in the central region (b) and the other two were lateral to the first (a-c, respectively).

The silicone present inside the sections was removed manually.

The three sections were submitted to conventional processing for histological examination, included in paraffin and cut with a manual microtome in a thickness of 2-micra. The sections were stained with hematoxilin and eosin (HE).

The microscope used for this analysis was the biocular ZEISS ${ }^{\circledR}$ (Mod. LABOVAL 4), fitted with an ocular grid previously calibrated with 100 divisions. This grid sets an area within the histological slice with $102 \mu^{2}$ (Figure 3 ). The morphometric analysis was conducted in two regions of the implant, a posterior one (between the skin and the implant) and an anterior one (between the implant and the aponeurosis).
In these regions two areas of $102 \mu^{2}$ were established, in which the following parameters were observed: Number of polymorphonuclears (PMN), number of mononuclears (MO), foreign-body type giant cells (CCG), macrophages and other cell types.

\section{Statistical evaluation}

The variance analysis was conducted to check the sample homogeneity through the Levene test. Descriptive measures, multivaried statistical procedures (Manova) and discriminating analysis were used. The significance level adopted was $\alpha=0.05$, and the tables where there was statistical significance were marked with a $\operatorname{star}(*)$.

\section{Results}

The fibrous capsule upper edge thickness average was $654.6 \mu$, with a standard deviation of $108.5 \mu$, median $641.7 \mu$, quartile $(\mathrm{Q}) 25=600 \mu$ and quartile $(\mathrm{Q}) 75=$ 705.0 $\mu$ (TABLE 1).

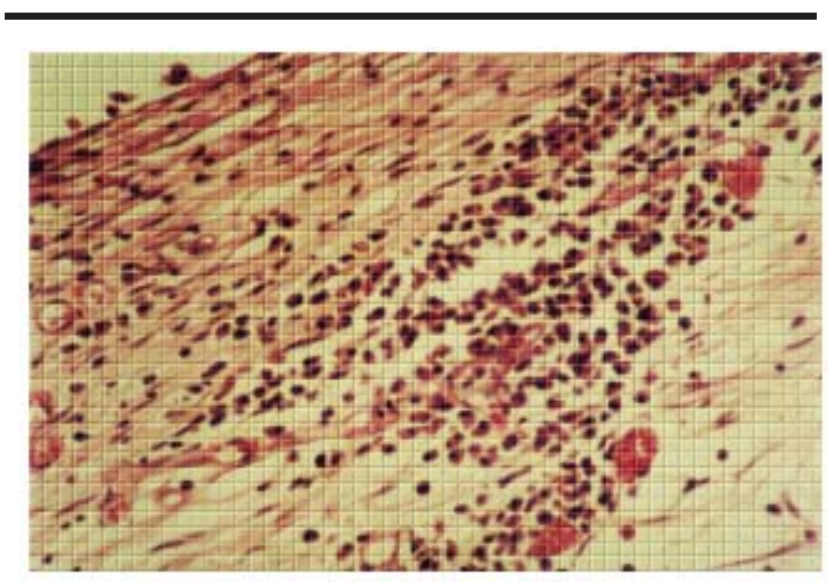

FIGURE 3 - Illustration used in morphometric grid with 102 $\mathrm{m}^{2}$ area.

TABLE 1 - Measures of the upper edge thickness, with arithmetical average, standard deviation, Q25, median, Q75 of all groups, individually and globally.

\begin{tabular}{llllll}
\hline Group & Average $(\boldsymbol{\mu})$ & Standard Deviation $(\boldsymbol{\mu})$ & $\mathbf{Q 2 5}(\boldsymbol{\mu})$ & Median $(\boldsymbol{\mu})$ & $\mathbf{Q 7 5}(\boldsymbol{\mu})$ \\
\hline 1 & 633.3 & 102.6 & 573.3 & 640.0 & 660.0 \\
2 & 773.8 & 99.9 & 694.2 & 762.5 & 853.3 \\
3 & 612.0 & 45.6 & 603.3 & 606.7 & 646.7 \\
4 & 669.3 & 100.0 & 600.0 & 643.3 & 713.3 \\
5 & 729.3 & 156.4 & 643.3 & 666.7 & 733.3 \\
6 & 628.3 & 66.0 & 606.7 & 623.3 & 673.3 \\
7 & 560.0 & 44.3 & 515.0 & 563.3 & 600.0 \\
\hline Overall & & $\mathbf{1 0 8 . 5}$ & $\mathbf{6 0 0 . 0}$ & $\mathbf{6 4 1 . 7}$ & $\mathbf{7 0 5 . 0}$ \\
Average & $\mathbf{6 5 4 . 6}$ & $\mathbf{6}$ & & \\
\hline
\end{tabular}

The fibrous capsule lower edge thickness average was $677.0 \mu$, with a standard deviation of $119.3 \mu$, of $119.3 \mu$, median $660.0 \mu, \mathrm{Q} 25=606.7 \mu$ e Q75 $=755.0 \mu$

(TABLE2) 
TABLE 2 - Measures of the lower edge thickness, with arithmetic average, standard deviation, Q25, median, Q75 of all groups, individually and globally.

\begin{tabular}{llllll}
\hline Group & Average $(\boldsymbol{\mu})$ & Standard Deviation $(\boldsymbol{\mu})$ & $\mathbf{Q 2 5}(\boldsymbol{\mu})$ & Median $(\boldsymbol{\mu})$ & $\mathbf{Q 7 5}(\boldsymbol{\mu})$ \\
\hline 1 & 679.3 & 58.4 & 645.0 & 676.7 & 690.0 \\
2 & 641.7 & 217.3 & 480.0 & 603.3 & 803.3 \\
3 & 632.3 & 46.3 & 620.0 & 630.0 & 665.0 \\
4 & 785.7 & 123.0 & 766.7 & 785.0 & 873.3 \\
5 & 583.3 & 74.0 & 540.0 & 550.0 & 650.0 \\
6 & 660.0 & 71.3 & 615.0 & 640.0 & 710.0 \\
7 & 749.3 & 120.2 & 655.0 & 750.0 & 850.0 \\
\hline Overall & & & & & $\mathbf{7 5 5 . 0}$ \\
Average & $\mathbf{6 7 7 . 0}$ & $\mathbf{1 1 9 . 3}$ & $\mathbf{6 0 6 . 7}$ & $\mathbf{6 6 0 . 0}$ & \\
\hline
\end{tabular}

The average number of mononuclear cells was 5.5 cells, Q25=3.67 cells and Q75=6.67 cells (TABLE 3). 5.63 cells, with a standard deviation of 2.61 cells, median

TABLE 3 - Measures of mononuclear cells (cells), with Arithmetical Average, Standard Deviation, Q25, Median, Q75 of all Groups, individually and globally.

\begin{tabular}{llllll}
\hline Groups & Average(cells) & Standard Deviation(cells) & Q25(cells) & Median(cells) & Q75(cells) \\
\hline 1 & 8.33 & 2.33 & 6.67 & 8.00 & 8.00 \\
2 & 6.88 & 0.53 & 6.58 & 6.67 & 7.17 \\
3 & 6.00 & 1.35 & 5.00 & 5.67 & 6.67 \\
4 & 5.73 & 1.94 & 4.67 & 5.33 & 5.67 \\
5 & 3.47 & 0.80 & 3.00 & 3.67 & 4.00 \\
6 & 2.83 & 0.55 & 2.67 & 3.00 & 3.00 \\
7 & 6.43 & 4.11 & 4.50 & 5.67 & 7.00 \\
\hline Overall & & & & & $\mathbf{5 . 5 0}$ \\
Average & $\mathbf{5 . 6 3}$ & $\mathbf{2 . 6 1}$ & $\mathbf{3 . 6 7}$ & $\mathbf{6 . 6 7}$ \\
\hline
\end{tabular}

The average number of polymorphonuclear cells Median 1.33 cells, Q25 $=0.67$ cells and Q75 $=1.67$ cells was 1.28 cells (cells), with Standard Deviation of 0.73 cells, $\quad$ (TABLE4).

TABLE 4 - Measures of polymorphonuclear cells (cells), with Arithmetical Average, Standard Deviation, Q25, Median, Q75 of all Groups, individually and globally.

\begin{tabular}{llllll}
\hline Group & Average(cells) & Standard Deviation(cells) & Q25(cells) & Median(cells) & Q75(cells) \\
\hline 1 & 1.60 & 0.49 & 1.33 & 1.67 & 1.67 \\
2 & 1.54 & 0.16 & 1.42 & 1.58 & 1.67 \\
3 & 1.57 & 0.43 & 1.33 & 1.50 & 2.00 \\
4 & 1.13 & 0.78 & 0.67 & 0.67 & 1.50 \\
5 & 1.87 & 1.07 & 1.33 & 1.33 & 0.007 \\
6 & 0.47 & 0.38 & 0.33 & 0.33 & 1.00 \\
7 & 0.83 & 0.41 & 0.50 & 1.00 & $\mathbf{1 . 6 7}$ \\
\hline Overall & & & & & $\mathbf{1 . 3 3}$ \\
Average & $\mathbf{1 . 2 8}$ & $\mathbf{0 . 7 3}$ & $\mathbf{0 . 6 7}$ & & \\
\hline
\end{tabular}

The Average number of giant cells was 3.38 cells $\quad$ cells, Q25=2.0 cells and Q75=4.67 cells (TABLE 5). (cells), with Standard Deviation of 1.79 cells, Median 3.0 
TABLE 5 - Measures of giant cells (cells), with Arithmetical Average, Standard Deviation, Q25, Median, Q75 of all Groups, individually and globally.

\begin{tabular}{|c|c|c|c|c|c|}
\hline Group & Average(cells) & Standard Deviation(cells) & Q25(cells) & Median(cells) & Q75(cells) \\
\hline 1 & 3.00 & 0.85 & 2.67 & 3.00 & 3.00 \\
\hline 2 & 1.92 & 0.74 & 1.50 & 1.67 & 2.33 \\
\hline 3 & 1.80 & 0.51 & 1.67 & 2.00 & 2.00 \\
\hline 4 & 1.87 & 0.99 & 1.67 & 2.00 & 2.33 \\
\hline 5 & 4.07 & 1.21 & 3.33 & 4.67 & 4.67 \\
\hline 6 & 4.53 & 0.96 & 3.67 & 5.00 & 5.33 \\
\hline 7 & 6.17 & 1.13 & 5.33 & 6.50 & 7.00 \\
\hline \multicolumn{6}{|l|}{ Overall } \\
\hline Average & 3.38 & 1.79 & 2.00 & 3.00 & 4.67 \\
\hline
\end{tabular}

The average number of isolated macrophage cells was 1.75 cells (cells), with Standard Deviation of 1.07 cells,
Median 1.67 cells, Q25 $=1.0$ cells and Q75 $=2.33$ cells (TABLE6).

TABLE 6 - Measures of isolated macrophage cells (cells), with Arithmetical Average, Standard Deviation, Q25, Median, Q75 of all Groups, individually and globally.

\begin{tabular}{llllll}
\hline Group & Average(cells) & Standard Deviation(cells) & Q25(cells) & Median(cells) & Q75(cells) \\
\hline 1 & 1.40 & 0.42 & 1.00 & 1.50 & 1.50 \\
2 & 2.33 & 0.82 & 1.67 & 2.50 & 3.00 \\
3 & 2.77 & 0.92 & 2.00 & 2.33 & 3.50 \\
4 & 2.30 & 1.39 & 1.67 & 2.50 & 3.00 \\
5 & 0.93 & 0.83 & 0.33 & 0.67 & 1.00 \\
6 & 1.53 & 0.99 & 1.33 & 1.67 & 2.00 \\
7 & 1.07 & 0.80 & 0.50 & 1.33 & 1.50 \\
\hline Overall & 1.75 & 1.07 & 1.00 & 1.67 & 2.33 \\
Average & & & & \\
\hline
\end{tabular}

CHART 1 - Comparison of group results obtained with and without the use of antimicrobials, as compared to the investigated cell types.

\begin{tabular}{lll}
\hline CELL TYPES/ Groups & without Antimicrobial & With Antimicrobial \\
\hline GIANT CELLS & $\downarrow^{* *}$ & $\uparrow^{*}$ \\
MONONUCLEAR CELLS & $\uparrow^{*}$ & $\downarrow^{* *}$ \\
ISOLATED MACROPHAGES & $\uparrow^{*}$ & $\downarrow^{* *}$ \\
POLYMORPHONUCLEAR CELLS & $\uparrow^{*}$ & $\downarrow^{* *}$ \\
POSTERIOREDGE & $\uparrow^{*}$ & $\downarrow^{* *}$ \\
ANTERIOREDGE & $\uparrow^{*}$ & $\downarrow^{* *}$ \\
\hline$* \uparrow:$ Increase in number of cells. & \\
$* * \downarrow$ : Decrease in number of cells. & \\
\hline
\end{tabular}

The analysis of variance homogeneity conditions, according to the LEVENE test, proved that the sample is homogeneous, since the probability of significance (p) was greater than or equal to 0.05 , for an adopted significance level $(\alpha)$ of 0.05 (TABLE 7). It is, therefore, accepted for the application of multi-varied variance analysis test
(MANOVA), in order to assess the differences in the findings of the 7 experimental groups. 
TABLE 7 - Analysis of the LEVENE variance homogeneity test of all variables.

\begin{tabular}{lll}
\hline Variables & F & p \\
\hline UpperEdge & 1.27 & $0.30^{*}$ \\
Lower Edge & 2.50 & 0.05 \\
Mononuclear cells & 2.20 & $0.07^{*}$ \\
Polymorphonuclear cells & 2.15 & $0.08^{*}$ \\
Giant cells & 1.19 & $0.34^{*}$ \\
Isolated macrophage cells & 1.05 & $0.42^{*}$ \\
\hline${ }^{*} \mathrm{p}>0.05$ & & \\
\hline
\end{tabular}

In the application of the Manova test, the WILKS' Lambda $(\lambda)$ obtained was 0.02326 and the probability of significance was $p=0.0000001$, showing that there was statistically significant histological difference among the groups.

It was observed that the control group had a central tendency in the distribution, point $(0 ; 0)$ (axis) and that the experimental groups II, III, IV were distributed to the right whereas groups V, VI and VII were distributed to the left.

TABLE 8 - Evaluation according to the discriminating analysis test.

\begin{tabular}{llc}
\hline CELLTYPE & LAMBDA WILKS & $\mathbf{p}$ \\
Giant Cells & 0.08 & $0.00^{*}$ \\
Mononuclear Cells & 0.04 & $0.03^{*}$ \\
Isolated Macrophage cells & 0.04 & 0.08 \\
Polymorphonuclear cells & 0.04 & 0.12 \\
Upper Capsular Edge & 0.03 & 0.17 \\
Lower Capsular Edge & 0.03 & 0.26 \\
\hline
\end{tabular}

\section{Discussion}

Wound healing is a dynamic process involving biochemical and physiological phenomena which behave in a harmonious way in order to ensure tissue restoration. The main factor which triggers healing is the local lesion with or without tissue loss, from which physiological events completely turn towards repairing that which caused damage to the integrity of the organism 9 .

In a clean surgical incision, neutrophils appear within 24 hours. There is thickening of the epidermis on the incisional edge, resulting from basal cell mitosis. Within 24 to 48 hours, a continuous thin epithelial layer is formed right under the superficial crust, resulting from the migration and growth of epithelial cells. Up until the third day neutrophils are, in their majority, replaced by macrophages which will reach their peak at 10 days. Granulation tissue invades the incision, with the appearance of collagen fibers on the incisional edges. By the fiveth day the incisional space is filled by granulation tissue ${ }^{10}$.

From the seventh day on there is fibroblast proliferation and continuous accumulation of collagen, with the disappearance of most of the leucocyte infiltrate, the edema and the increased vascularization. The scar becomes pale due to the presence of collagen.

In the clean surgical wound, maximum neovascularization takes place at five days. Collagen becomes abundant and epidermial architecture is recovered, with superficial keratinization.

At the end of the first month the scar is represented by connective tissue free of inflammatory infiltrate.

Many variables, both general as well as local, influence the long and complex healing process.

We observed that silicone implants are not free of complications, capsular contracture being the main complication and the greatest cause of complaint and frustrations in augmentation mammoplasty, both for aesthetical as well as for repair purposes.

The main microorganisms found in breast implants or in the fibrous capsule formed around the prostheses are: Staphylococcus epidermidis (S. epidermidis), Staphylococcus aureus, Escherichia coli, Pseudomonas e Propionibacterium acnes. The $S$. epidermidis, mentioned by several authors, is considered to be the main causal agent of capsular contracture ${ }^{11,12,13}$.

After this finding, this was the microorganism of choice for the contamination of implants carried out in this study.

There are many papers with conflicting results and different methodologies, all utilizing implants which present varied and very high incidence of capsular contracture (10$90 \%$ ) when compared to polyurethane-coated implants (1 $4 \%)$.

Although the ideal implant has not been invented yet, the polyurethane-coated silicone gel one has clinically 
demonstrated a lower incidence of capsular contracture. In order to eliminate one more variable which may interfere with capsular contracture with regards to implant material, the use of polyurethane-coated silicone implants was established.

Histologically, $\mathrm{SHAH}^{14}$ demonstrated that the contaminated implants' fibrous capsules were 2 to 3 times thicker, with more fibrosis and with abundant collagen formation and intense cellular infiltrate with white blood cells and macrophage cells. On the other hand, noncontaminated fibrous capsules were thinner, consisting of an organized connective tissue of fibers predominantly parallel to the surface of the prostheses.

The above findings are contradictory with the present study with regards to capsular contracture, and no correlation between contamination and thickness was verified.

With regards to cellularity, the results obtained are similar to those found in the literature, in spite of the fact that there is no detailed morphometric description in the investigated studies.

In the present study, a peri-implant chronic granulomatose inflammatory reaction was observed.

The presence of a greater number of cells characterizing acute inflammatory pattern (polymorphonuclear cells) was observed in the contaminated group with no antimicrobial solution. Literature mentions that the presence of a greater number of neutrophils in a chronic inflammation may be induced by persistent bacterial presence, necrotic cells, or by mediators produced by macrophage cells ${ }^{15}$.

The evaluation through the discriminating analysis test proved that the most important and statistically different result among the groups was the number of giant cells and of mononuclear cells. Groups V, VI and VII were observed to have the greatest number of foreign body giant cells as compared to groups II, II and IV, which had a lower number. With regards to mononuclear cells, groups V, VI and VII had a lower number, whereas Groups II, III and IV had a greater number.

Such findings concerning the discriminating factors above suggest that the greatest stimulation caused by bacterial contamination without the use of antimicrobial agents led to a greater activation of mononuclear cells. On the other hand, in the group in which an antimicrobial agent was used there was lower activation of mononuclear cells, accounting for a more intense granulomatose inflammatory pattern, indirectly proving the effect of the antimicrobial solution in the decrease of mononuclear cell inflammatory reaction, thus favoring foreign body response.

According to the literature, in an inflammatory process, the greater the number of mononuclear cells, especially macrophage cells, the greater tissue damage there will be, the greater the angiogenesis, the number of fibroblasts and, consequently, the greater the fibrosis.

There is, therefore, the need to create new research work to determine whether in the long run these chronic granulomatose inflammatory reactions will be responsible for peri-implant alterations to the extent of causing the most common and most important of all complications: capsular contracture.

\section{Conclusions}

1. The histological pattern of the inflammatory reaction around polyurethane-coated silicone implants is the foreignbody granulomatose chronic type.

2. There is no correlation between the concentration of Staphylococcus epidermidis bacteria and morphometric alterations.

3. The use of an antimicrobial solution decreases mononuclear cell reaction, with an increase in foreign-body giant cells.

\section{References}

1. Uchida J. Clinical Application of cross-linked dimethylpolysiloxane; restoration of breast, chest, atrophy of infantile paralysis, funnel-shaped chest, etc. JPN J Plast Reconstr Surg 1961; 4:303-9.

2. Kopf EH, Vinnik CA, Bongiovi JJ, Dombrowski DJ. Complications of silicone injections. Rocky Med J 1976; 73:77-80.

3. Ortiz-Monasterio F, Trigos I. Management of patients with complications from injections of foreign material into the breast. Plast Reconstr Surg. 1972; 50: 42-7.

4. Caffe HH. The influence of silicone bleed on capsular contracture. Ann Plast Surg 1986;17(4): 284-7.

5. Melmed E. Polyurethane implants: a six year review of 416 patients. Plast Reconstr Surg 1988; 82:285-90.

6. Hester R, Nahai F, Bostwick J, Cukic J. A 5 year experience with polyurethane-covered mammary prostheses for tretment of capsular contracture, primary augmentation mammaplasty, and breast reconstruction. Clin Plast Surg 1988; 15: 569-85.

7. Shapiro M. Smooth VS. Rough: um 8 years survey of mammary prosthese. Plast Reconstr Surg 1989; 84: 449-57.

8. Adams WP Jr, Conner WC et al. Optimizing breast pocket irrigation: na in vitro study and clinical implications. Plast Reconstr Surg 2000; 105(1): 334-43.

9. Watson J. Some observations on fre fat grafts, with reference to their use in mammaplasty. Br J Plast Surg 1959; 12: 263-74.

10. Edgerton MT, McClary AR. Augmentation mammaplasty. Plast Reconstr Surg 1958; 21:279-305.

11. Dobke MK, Svahn JK et al. Characterization of microbial presence at the surface of silicone mammary implants. Ann Plast Surg 1995; 34(6): 563-71.

12. Ahn CY, Ko CY et al. Microbial evaluation: 139 implants removed from symptomatic patients. Plast Reconstr Surg 1996; 98: 1225-9. 
13. Netscher DT, Weizer G et al. Clinical relevance of positive breast periprosthetic cultures without overt infection. Plast Reconstr Surg 1995; 96: 1125-9.

14. O`Connor CM. Glandular excision with immediate mammary reconstruction. Plast Reconstr Surg 1964; 33:5760.

15. Goulian D Jr, McDivitt RW. Subcutaneous mastectomy with immediate reconstruction of the breast using the dermal mastopexy technique. Plast Reconstr Surg 1972; 50: 211-5.

\section{Correspondence:}

Jorge Bins Ely

Rua Dep. Antonio Edu Vieira, 1414

88040-001 Florianópolis-SC Brazil

Phone (55 48)3234-9494

jorge.binsely@gmail.com
Conflict of interest: none Financial source: none

Received: August 29, 2007

Review: October 23, 2007 Accepted: November 26, 2007

\section{How to cite this article}

Mendes PRS, Ely JB, Lima EAS, Vasconcellos ZAA, d'Acampora AJ, Neves RE. Histological study on acute inflammatory reaction to polyurethane-coated silicone implants in rats. Acta Cir Bras. [serial on the Internet] 2008 JanFeb;23(1). Available from URL: http://www.scielo.br/acb 